Огляди літератури, оригінальні дослідження, погляд на проблему, ювілеї

УДК 613.31:546.32/. 33-06:616.155.3]-092.9

DOI 10.11603/1811-2471.2018.v0.i2.8573

\title{
ВПЛИВ АЦЕТАТУ СВИНЦЮ ТА СТЕАРАТІВ НАТРІЮ І КАЛІЮ НА ПОКАЗНИКИ ПЕРИФЕРІЙНОЇ КРОВІ ПІДДОСЛІДНИХ ТВАРИН
}

\author{
๑о. Є. Федорів, О. Є. Копач, Н. А. Мельник \\ ДВНЗ «Тернопільський державний медичний університет імені І. Я. Горбачевського МОз України»
}

РЕЗЮМЕ. Однією із найтоксичніших для людського організму речовин $\epsilon$ свинець та його сполуки. Сполуки свинцю, що потрапляють зі стічними водами у водойми, можуть контактувати з поверхнево-активними речовинами (ПАР), типу стеаратів натрію і калію, та здатні впливати як на токсичність, так і на проникність важких металів в організм теплокровних тварин.

Мета - вивчити вплив ацетату свинцю в комбінації зі стеаратами натрію і калію на показники периферійної крові піддослідних тварин.

Матеріал і методи. Було проведено досліди на 4 групах білих щурів, яким перорально вводили ацетат свинцю на фоні споживання тваринами вод із вмістом стеаратів натрію та калію. Після 40-денного вживання цих вод тваринам перорально вводили ацетат свинцю, а через три доби робили мазки крові.

Результати. При комбінованому надходженні сполук свинцю в організм піддослідних тварин відмічалося збільшення кількості паличкоядерних нейтрофілів та еозинофілів і, водночас, зменшення сегментоядерних нейтрофілів.

Висновок. Встановлено, що при комбінованій дії ацетату свинцю в поєднанні зі стеаратами у крові піддослідних тварин збільшується кількість паличкоядерних нейтрофілів і еозинофілів, порівняно з контролем, та зменшується кількість сегментоядерних нейтрофілів.

КЛючОВІ СЛОВА: ацетат свинцю; питна вода; стеарат натрію; стеарат калію; лейкоцити; еритроцити.

Вступ. 3 кожним роком довкілля зазнає все більшого антропогенного навантаження, особливо важкими металами, серед яких особливе місце займають свинець і його сполуки. Ці речовини широко використовуються в промисловості: машино- та приладобудуванні, радіоелектроніці тощо $[1,2]$. Вони характеризуються високою токсичністю і підвищеною здатністю до кумуляції в організмі людини й тварин, що зумовлює їх небезпечність [3-5].

Мета - вивчити вплив ацетату свинцю в комбінації зі стеаратами натрію і калію на показники периферійної крові піддослідних тварин.

Матеріал і методи дослідження. Було проведено досліди на 4 групах білих щурів, яким перорально вводили ацетат свинцю в дозі 7 мг/100 г маси тіла (1/110 лД 50 на фоні споживання тваринами вод із вмістом стеаратів натрію та калію. 1 група тварин була контрольною і споживала воду з міського водогону. 2 група споживала таку ж воду, як i 1, 3 та 4 - споживали воду, збагачену, відповідно, стеаратом натрію і стеаратом калію, в дозі 1/250 ЛД $_{50}$. Після 40-денного вживання вказаних вод тваринам усіх груп, крім першої, перорально вводили ацетат свинцю в дозі 7 мг/кг. Через три доби робили мазки крові досліджуваних тварин.

Результати й обговорення. Кількістьпаличкоядерних нейтрофілів у тварин 3 групи була у 2,3 раза більшою, порівняно з тваринами контрольної групи: $(5,86 \pm 0,77) \%$ проти $(2,57 \pm 0,30) \%(p<0,01)$, та у 1,4 раза більшою, ніж у тварин 2 групи: $(5,86 \pm$ $0,77)$ \% проти $(4,14 \pm 0,46) \%$. У периферійній крові білих щурів 2 групи кількість сегментоядерних нейтрофілів була у 1,7 раза меншою, ніж у контролі $(p<0,001):(7,86 \pm 0,55) \%$ проти $(13,00 \pm 0,65) \%$. У тварин 4 групи кількість клітин була 1,2 раза меншою $((11,00 \pm 0,31) \%$ проти $(13,00 \pm 0,65) \%)$, ніж у інтактних тварин $(p<0,05)$. У тварин 2 та 4 груп кількість еозинофілів у периферійній крові виявилася однаковою, проте була у 1,2 раза вищою, ніж у контрольній $((2,14 \pm 0,14) \%$ проти $(1,86 \pm 0,26) \%)$ та у 3 групах тварин.

Висновки. При комбінованій дії ацетату свинцю в поєднанні з стеаратами спостерігалося збільшення у крові кількості паличкоядерних нейтрофілів у 1,5-1,8 раза, еозинофілів - у 2,53,4 раза, порівняно з контролем $(p<0,01)$, та зменшення кількості сегментоядерних нейтрофілів в крові піддослідних тварин у 1,3-1,5 раза $(p<0,01)$.

\section{ЛІТЕРАТУРА}

1. Гильденскиольд Р. С. Тяжелые металлы в окружающей среде и их влияние на организм (обзор) / Р. С. Гильденскиольд, Ю.В.Новиков, Р. С. Хамидули // Гигиена и санитария. - 1992. - № 56. - С. 69.

2. Шумейко В. М. Екологічна токсикологія: предмет, поняття, джерела виникнення / В. М. Шумейко, В. М. Овруцький, І. В. Глуховський // Сучасні проблеми токсикології. - 1998. - № 1. - С. 55-63. 
Огляди літератури, оригінальні дослідження, погляд на проблему, ювілеї

3. Level of oxidative stress and damage in erythrocytes in apprentices indirectly exposed to lead / I. Ergurhan-Ilhan, B. Cadir, M. Koyuncu-Arslan [et al.] // Pediatr Int. - 2008. - Vol. 50, No. 1. - P. 45-50.

4. Patrick L. Lead toxicity Part II: The role of free radical damage and the use of antioxidants in the pathology and treatment of lead toxicity / L. Patrick // Alternative Medicine Review. - 2006. - Vol. 11, No. 2. - P. 114-127.

5. Immunotokxicity of co exposures to heavy metals: In vitro studies and results from occupational exposure to cadmium, cobalt and lead / D. Jung, U. Bolm Audorff, A. Faldum [et al.] // EXCLI Journal. - 2003. - No. 2. - P. 31-44.

\title{
REFERENCES
}

1. Gildenskiold, R.S., Novikov, Yu.V., \& Khamiduli, R.S. (1992). Tyazhelye metally $v$ okruzhayushchey srede $\mathrm{i}$ ikh vliyanie na organizm (obzor) [Heavy metals in environment and their influence on the body (review)]. Gigiyena $i$ sanitariya - Hygiene and Sanitary, 56, 69 [in Russian].

2. Shumeiko, V.M., Ovrutskyi, V.M., \& Hlukhovskyi, I.V. (1998). Ekolohichna toksykolohiia: predmet, poniattia, dzherela vynyknennia [Ecological toxicology: subject, meaning, sources of origin]. Suchasni problemy toksykolohiiModern Problems of Toxicology, 1, 55-63 [in Ukrainian].

3. Ergurhan-Ilhan, I., Cadir, B., \& Koyuncu-Arslan, M.

(2008). Level of oxidative stress and damage in erythrocytes in apprentices indirectly exposed to lead. Pediatr. Int., 50 (1), 45-50.

4. Patrick, L. (2006). Lead toxicity Part II: The role of free radical damage and the use of antioxidants in the pathology and treatment of lead toxicity. Alternative Medicine Review, 11 (2), 114-127.

5. Jung, D., Bolm Audorff, U., \& Faldum, A. (2003). Immunotoxicity of co exposures to heavy metals: In vitro studies and results from occupational exposure to cadmium, cobalt and lead. EXCLI Journal, 2, 31-44.

\section{ВЛИЯНИЕ АЦЕТАТА СВИНЦА И СТЕАРАТОВ НАТРИЯ И КАЛИЯ НА ПОКАЗАТЕЛИ ПЕРИФЕРИЧЕСКОЙ КРОВИ ПОДОПЫТНЫХ ЖИВОТНЫХ}

\author{
๑О. Е. Федоров, О. Е. Копач, Н. А. Мельник
}

ГВУз «Тернопольский государственный медицинский университет мени И. Я. Горбачевского МЗ Украины»

РЕЗЮМЕ. Одним из самых токсичных для человеческого организма веществ является свинец и его соединения, которые широко используются в промышленности. Попадая со сточными водами в водоемы, соединения свинца могут контактировать с поверхностно-активными веществами, в том числе анионными ПАВ, типа стеаратов натрия и калия, которые способны влиять как на токсичность, так и на проницаемость тяжелых металлов в организм теплокровных животных.

КЛЮЧЕВЫЕ СЛОВА: ацетат свинца; питьевая вода; стеарат натрия; стеарат калия; лейкоциты; эритроциты.

\section{EFFECT OF LEAD ACETATE WITH POTASSIUM AND SODIUM STEARATES ON THE PERIPHERAL BLOOD OF EXPERIMENTAL ANIMALS}

\author{
@OO. E. Fedoriv, O. E. Kopach, N. A. Melnyk \\ I. Horbachevsky Ternopil State Medical University
}

SUMMARY. Among the most toxic substances in the human body, lead and its compounds are widely used in industry. When they come into contact with waste water in the reservoir, lead compounds may come into contact with surface-active substances, including anionic surfactants, such as sodium and potassium stearates, which can affect both the toxicity and the permeability of heavy metals to the body of warm-blooded animals.

KEY WORDS: lead acetate; drinking water; sodium stearate; potassium stearate; leukocytes; erythrocytes.

Отримано 11.02.2018 